\title{
O PEWNYM DWUGŁOSIE W SZKOLE LWOWSKO- -WARSZAWSKIEJ. NORMATYWNOŚĆ MIĘDZY ETOLOGIĄ A ETYKĄ EMPIRYCZNĄ
}

\begin{abstract}
Streszczenie. Artykuł krytycznie eksplikuje perspektywę etologiczną i etyczno-empiryczną refleksji nad moralnością, które pojawiają się w ramach szkoły lwowsko-warszawskiej. Poprzez odwołanie się do badań Marii Ossowskiej wyeksponowana zostaje skłonność analiz etologicznych do anihilacji specyfiki normatywności moralnej (imperatywności moralnej), jak również niejednoznaczność wniosków samej Marii Ossowskiej i jej predylekcja ku emotywizmowi. Eksploracja myśli Tadeusza Czeżowskiego natomiast odsłania naukowy (empiryczny) status norm aksjologicznych i deontycznych, które mogą być uznawane za zdania prawdziwe bądź fałszywe. Finalnie model normatywności Marii Ossowskiej i Tadeusza Czeżowskiego zostaje skonfrontowany z imperatywnością moralną dostępną na poziomie doświadczalnej datum morale.
\end{abstract}

Słowa kluczowe: etologia, etyka empiryczna, nauka, normatywność, imperatywność moralna

1. Zamiast wstępu. 2. Etologiczne zagubienie normatywności. 3. Ku naukowości normatywności moralnej. 4. Podsumowanie.

\section{ZAMIAST WSTĘPU}

Prezentowane rozważania mają na celu eksplikację problemu normy moralnej w perspektywie badań szkoły lwowsko-warszawskiej. Rozprawa ma charakter jedynie pewnego szkicu i nie pretenduje do kompleksowego ujęcia koncepcji normatywności uczniów Kazimierza Twardowskiego. Mając świadomość liczności szkoły, jej wielopokoleniowości (Marię Ossowska można wszak traktować jako „naukową wnuczkę" Twardowskiego), jak również tego, że poglądy założyciela szkoły lwowsko-warszawskiej „zostały znacznie przetworzone, 
zmienione i zastąpione innymi"1, zaprezentujemy jedynie pewien dwugłos etyczny.

Nasze badania skoncentrujemy na normatywności moralnej odsłanianej w optyce etologii Marii Ossowskiej i etyki empirycznej Tadeusza Czeżowskiego, które z jednej strony wskazują na pewną możliwą dwubiegunowość naukowego dyskursu etycznego, a z drugiej mogą skłaniać do dalszego metaetycznego namysłu. Tytułem uściślenia dodajmy, że drugi komponent tytułowego dwugtosu (refleksja Tadeusza Czeżowskiego) powstał niezależnie od dyskursu Marii Ossowskiej.

\section{ETOLOGICZNE ZAGUBIENIE NORMATYWNOŚCI}

Maria Ossowska dystansowała się od terminu 'etologia’. Stwierdziła wyraźnie, że „wolimy nazwę »nauka o moralności« niż proponowaną przez niektórych nazwę »etologia« (...), gdyż ta ostatnia (...) nie odpowiada problematyce, którą zarysowaliśmy"2. Jeżeli jednak mamy świadomość utrwalonej w literaturze terminologii ${ }^{3}$, to za uzasadnione należy uznać twierdzenie, że wariant refleksji etycznej realizowany przez Ossowską konsekwentnie wpisywał się w model badań etologicznych. Już sam projekt nauki o moralności stanowił wyraz etologicznego zorientowania dalszych badań. Jeżeli bowiem - jak pisze

1 J. Woleński, Filozoficzna szkoła Iwowsko-warszawska, PWN, Warszawa 1985, 309.

2 M. Ossowska, Podstawy nauki o moralności, Warszawa 1963, 18. Por. taż, Jakie zadania ma przed sobq̨ badacz moralności?, w: taż, O człowieku, moralności i nauce. Miscellanea, Warszawa 1983, 338n.

3 „Celem etologii - pisał Szostek - jest opis moralności pojętej jako zespół moralnych przekonań i przeżyć, a także podległych ocenie moralnej zachowań jednostek i grup społecznych, oraz wyjaśnianie moralności przez kulturowe, historyczne, psychologiczne i społeczne uwarunkowania". A. Szostek, Etologia, w: Leksykon filozofii klasycznej, red. J. Herbut, Lublin 1997, 173. Por. A. Podsiad, Etologia, w: Słownik terminów i pojęć filozoficznych, Warszawa 2000, 240n; T. Styczeń, Etyka, w: Powszechna encyklopedia filozofii, red. A. Maryniarczyk i in., Lublin 2002, t. 3, 269n; T. Styczeń, Zarys etyki. Metaetyka, Lublin 1974, 23nn. 
Ossowska - nazywać będziemy „nauką o moralności dyscyplinę, która niczego w zakresie moralności nie ocenia i niczego nie zaleca, tylko próbuje np. jak najrzetelniej zanalizować i wyjaśnić panujące w danym środowisku oceny moralne i obowiązujące w nim normy, próbuje dociec motywów, które pchają ludzi zarówno do chwalonego, jak i ganionego w danym środowisku postępowania”4 i jeżeli „tego, kogo sprawy moralności interesują w sposób czysto faktyczny, kto $\mathrm{w}$ tym zakresie wstrzymuje się od wszelkiego oceniania i pragnie tylko wiedzieć, jak rzeczy stoją, nie zaś jak stać powinny (...) nazywać będziemy badaczem moralności”' to pozostawanie badacza moralności wyłącznie na gruncie etologicznym wydaje się oczywiste.

Tym bardziej jest to oczywiste, że etyka normatywna zostaje przez preferowaną przez Ossowską koncepcję refleksji nad moralnością wchłonięta nie tylko w perspektywie faktycznych analiz, lecz już w samym metodologicznym ich zamyśle. Ten ostatni motyw odsłania się wyraźnie w dłuższej - znaczącej dla naszych badań - wypowiedzi autorki. Twierdzi ona, że „etyka będzie pewną dyscypliną głoszącą, co jest dobre i co jest złe moralnie, dyscypliną zalecającą, co się powinno robić i czego należy unikać, etycznymi zaś będą wypowiedzi wchodzące w skład tej dyscypliny. Tak rozumiana etyka wchodzić będzie w skład moralności epoki, w której powstała, przy rozumieniu przez moralność ogółu wypowiadanych w danej epoce i w danym środowisku ocen i norm (...). Każda ocena etyczna byłaby jednocześnie oceną moralną, ale nie na odwrót, tzn. nie każda ocena moralna jest cechą skodyfikowaną w jakimś systemie. Poglądy głoszone w etykach stałyby się w ten sposób wycinkiem naszego życia moralnego"6.

W optyce wyznaczonej przytoczoną wypowiedzią, możemy zauważyć postulatywną resorpcję oceniającej i normującej etyki przez naukę o moralności. Ta ostatnia bowiem - w samej istocie

4 M. Ossowska, Podstawy nauki o moralności, dz. cyt., 10.

5 Taż, Jakie zadania ma przed sobą badacz moralności?, dz. cyt., 333.

6 Taż, Podstawy nauki o moralności, dz. cyt., 19n. 
jej programu - postuluje nie tylko to, aby badania skoncentrować na perspektywie socjologicznej, historycznej czy psychologicznej ${ }^{7}$, w której ujmować można faktycznie funkcjonujące schematy oceniające czy normatywne (towarzyszące realnym społecznościom), lecz wspominana nauka o moralności ma zająć się istniejącymi systemami etycznymi. W konsekwencji badacz moralności zajmuje wobec istniejących systemów etycznych pozycje obiektywnego, niezaangażowanego obserwatora, który w swoisty sposób neutralizuje normatywny status wypowiedzi współ-konstytuujących dany system etyczny. Owe wypowiedzi przecież stają się swoistym materiałem faktograficznym, wobec którego adekwatnym językiem będzie język opisowy, pozostający w radykalnym dystansie wobec języka oceniającego ${ }^{8}$.

Szczególnym potwierdzeniem naszej sugestii o etologicznym zawłaszczeniu normatywności poprzez realizatora idei nauki o moralności autorstwa Ossowskiej jest stwierdzenie, że „oceny i normy, które proponują etycy od siebie, bywają zwykle charakterystyczne dla danej epoki (...). Stąd systemy etyczne z pewnymi zastrzeżeniami można poczytywać za materiał dla badań nad moralnością epoki, w której powstały" . Badacz moralności winien więc zdystansować się nie tylko wobec wypowiedzi oceniających i normotwórczych pojawiających się w szacie języka potocznego, lecz także wobec spójnych i skodyfikowanych systemów etycznych. Owo zdystansowanie się wobec jakiegokolwiek normatywno-moralnego dyskursu - ujmowanie go $\mathrm{z}$ metapoziomu - jest doniosłym postulatem koncepcji Ossowskiej.

7 Por. T. Biesaga, Ossowska Maria, w: Powszechna encyklopedia filozofii, red. A. Maryniarczyk i in., Lublin 2006, t. 7, 891; J. Rutkowska-Hajduk, Ossowska Maria, WWW.ptta. pl/pef/pdf/ossowska.pdf [pobrano: 7.11.2016].

8 Maria Ossowska stwierdza, że odróżniając „naukę o moralności od etyki posługiwaliśmy się rozróżnieniem dwóch typów wypowiedzi: wypowiedzi opisowych i oceniających. Naukę o moralności próbowaliśmy zbudować z wypowiedzi opisowych, na etykę złożyć się miały pewne oceny i normy (...). Możemy się spotkać z oceną w nauce o moralności, ale tylko w charakterze przedmiotu badania”. M. Ossowska, Podstawy nauki o moralności, dz. cyt., 48.

9 Tamże, 21. 
Jeżeli równocześnie mamy świadomość, że Ossowska proponuje, aby badać zjawiska moralne „podobnie jak botanik bada rośliny, a językoznawca - zjawiska językowe"10, to zdaje się to potwierdzać naszą wcześniejsza tezę o zredukowaniu normatywno-etycznego poziomu refleksji nad moralnością do poziomu zdystansowanej, a-normatywnej etologicznej eksploracji tego, co inni uważają za istotne dla moralności, np. do faktycznych poglądów odnoszonych do ocen czy norm moralnych, nawet, jeżeli owymi innymi będą autorzy naukowo opracowanych systemów etycznych.

W tym miejscu warto odwołać się do Jana Woleńskiego, który stwierdza, że Ossowska „rozróżnia etykę opisową (= nauka o moralności) oraz etykę normatywną (= formułowanie zaleceń moralnych), ale uznaje, że obie »etyki« charakteryzują się odmiennym porządkiem epistemologicznym - tylko etyka opisowa jest nauką"11. Nieco dalej ten sam autor zauważy także, że „Ossowska bardzo rygorystycznie przestrzegała różnicy pomiędzy etyką opisową i normatywną. Oczywiście, etyka opisowa, a zwłaszcza psychologia i socjologia moralności, jest możliwa jako normalna nauka empiryczna; w kwestii możliwości naukowej etyki normatywnej Ossowska zawieszała swe stanowisko, ale $\mathrm{z}$ wielu jej uwag można odczytać daleko idący sceptycyzm wobec takiego przedsięwzięcia"12. Podobny wydźwięk ma konstatacja Tadeusza Biesagi, że „wyodrębnienie przez nią [Ossowską - W.K.] nauki o moralności (...) będzie równocześnie służyć podkreślaniu tego, że etyka normatywna taką nauką nie jest" ${ }^{13}$.

10 Tamże, 9. Ija Lazari-Pawłowska powie, że Ossowska „studentów usiłowała wdrożyć do tego, aby umieli obserwować zjawiska moralne równie beznamiętnie i rzeczowo, jak botanik obserwuje rośliny, i aby opisu zjawisk moralnych nie zniekształcali pod wpływem własnych niechęci lub upodobań”. I. Lazari-Pawłowska, Maria Ossowska jako badacz moralności, w: taż, Etyka. Pisma wybrane, red. P. J. Smoczyński, Wrocław-Warszawa-Kraków 1992, 431.

11 J. Woleński, Filozoficzna szkoła lwowsko-warszawska, dz. cyt., 285.

12 Tamże, 290.

13 T. Biesaga, Ossowska Maria, dz. cyt., 891. 
Dla naszych rozważań powyższe stwierdzenia są znaczące. Wskazują one nie tylko na postulowaną relację pomiędzy nauką o moralności i etyką, lecz także de facto odsłaniają status normatywności moralnej w perspektywie badań Marii Ossowskiej. Normy moralne przecież zostają przez badacza moralności ogołocone - poprzez fundamentalne odebranie im atrybutu naukowości $-\mathrm{z}$ jakiejkolwiek możliwości obiektywnego (!) przypisania im moralnej słuszności czy prawdziwości ${ }^{14}$. Roszczenie do ważności, swoiste zobowiązanie towarzyszące moralnej normatywności (imperatywność normy moralnej) ulega zasadniczej neutralizacji w spojrzeniu badacza moralności. Norma nie tyle jest już semantycznie sprecyzowanym moralnym zobowiązaniem, ile przedmiotem wnikliwej eksploracji naukowca konkretyzującego program nauki o moralności; przedmiotem, który w tej optyce przestaje stanowić obiektywny pogłos doświadczenia moralnej powinności i jako taki przestaje zobowiązywać badacza do respektowania treści normy. Normę moralną można wówczas poddać wnikliwej i wszechstronnej analizie semantycznej, socjologicznej czy psychologicznej, jednak za cenę pozbawienia jej normatywnej obowiązywalności. Inaczej mówiąc - oryginalność wypowiedzi moralno-normatywnej właśnie jako wypowiedzi moralnie zobowiązującej zostaje metodologicznie przekreślona już poprzez same principia metodologiczne nauki o moralności.

Warto w tym miejscu przywołać samą Marię Ossowską, która przy okazji poszukiwań swoistości norm moralnych - stwierdza, że „nie natrafiliśmy w toku naszych rozważań nad normą na żadne specyficznie moralne znaczenie słowa "powinien «"15, jak również konstatuje, że „nie umiemy podać specyficznie moralnych znaczeń tych słów [powinien i dobry - W.K.], co skłania nas do przypuszczenia,

14 O słuszności norm moralnych mówi m.in. Roman Ingarden: „Normy są »słuszne « lub »niesłuszne«, nie zaś prawdziwe lub fałszywe”. R. Ingarden, Wykłady z etyki, Warszawa 1989, 18.

15 M. Ossowska, Podstawy nauki o moralności, dz. cyt., 174. 
że oceny i normy stają się moralnymi nie dlatego, że w nich użyto specjalnych terminów, tylko że te terminy nabierają dla nas jakiegoś odcienia znaczeniowego, gdy występują w ocenach i normach uznanych przez nas już uprzednio na podstawie jakichś innych znamion za moralne"16. Za ewentualne inne znamię zostaje uznane przeżycie powinności dotyczące norm moralnych czy wyrzut sumienia. Jednak i w tym kontekście aktywność badacza moralności okazuje się nieskuteczna, czego przykładem może być chociażby stwierdzenie, że nietrudno „byłoby znaleźć człowieka, który by przyznał, że przy konflikcie reguły, opatrzonej w jego środowisku etykietą reguły moralnej i uznawanej przez niego za słuszną, z jakimś pragnieniem, wiodącym go w innym kierunku, idzie czasem za swoim pragnieniem, nie doznając żadnego gniotącego p o c zu c i a powinności i żadnych wyrzutów sumienia [podk. W.K.]"17.

Powyższe uwagi - stanowiące jedynie wybrane momenty etologicznej eksploracji kontekstu towarzyszącego problematyce norm moralnych ${ }^{18}$ - symptomatycznie odsłaniają bezradność etologa, który nie jest w stanie dotrzeć do istoty normy moralnej. Przyjęte założenia metodologiczne nauki o moralności pociągają za sobą niemożność wyłuskania swoistego rdzenia normatywności moralnej jako takiej. Można oczywiście skonstatować faktyczny brak przeżyć powinności oryginalnie moralnej czy brak wyrzutu sumienia, podobnie jak można zaprezentować argumentację wskazującą na niemożność odszukania specyficznie moralnego znaczenia terminów typu dobry, zty, powinność etc. Podobnych faktów - m.in. niejasności pewnych wypowiedzi normatywnych, wielości koncepcji etycznych dotyczących statusu normy moralnej, a także sposobów uzasadniania norm

16 Tamże, 176.

17 Tamże, 179.

18 Dyskusja wokół norm moralnych objęła m.in. teorie dotyczące społecznej ich genezy czy motywów respektowania norm, czego swoistym uzupełnieniem okazała się prezentacja stanowisk dotyczących ocen moralnych, wolności woli człowieka, zgodności działania z przekonaniami itp. Por. tamże, 195-249. 
moralnych czy wreszcie wielości faktycznych poglądów tyczących relacji pomiędzy normą moralną a normami pozamoralnymi można przytoczyć wiele ${ }^{19}$.

Jednak efektem tej pracy jest jedynie, z jednej strony, umykanie oryginalności normatywności moralnej (mimo wzrostu danych faktyczno-moralnych, czyli istniejących opinii), zaś z drugiej-brak jednoznacznego stanowiska samej Marii Ossowskiej wobec istoty normy moralnej20. Dokładniej mówiąc - ów brak jednoznaczności identyfikuje się z przyznaniem się autorki Norm moralnych do niepowodzenia w dążeniu do eksplikacji istoty moralnej normatywności. W takim przecież duchu można odczytać wypowiedź, w której Ossowska zauważy, że „wszystkie znane nam propozycje odpowiedzi na pytanie, czym różnią się (...) normy moralne od innych norm, jak np. norm prawnych, grzeszyły wspólnym błędem: usiłowaniem objęcia w jednym sformułowaniu spraw różnych w przekonaniu, że mają

19 Tytułem przykładu wspomnianej różnorodności poglądów wspomnijmy, że Ossowska stwierdza, że „do bardzo popularnych należy pogląd, w myśl którego norma moralna różni się od normy prawnej tym, co grozi człowiekowi w razie przekroczenia jednej i drugiej” (tamże, 296), ale nieco dalej już wskaże na koncepcję Leona Petrażyckiego, w myśl której „podczas gdy normy moralne mają charakter jednostronny, obciążając jedną, nie przyznają drugiej osobie niczego, normy prawne mają charakter dwustronny". Tamże, 298.

20 Ów brak jednoznacznego stanowiska Marii Ossowskiej stanowi zresztą swoiste znamię większości jej badań. W kontekście Podstaw o moralności Woleński zauważy, że „autorka dokonuje szczegółowego rozbioru podstawowych sporów metaetycznych. Natomiast w żadnej niemal kwestii nie zajmuje własnego stanowiska”. J. Woleński, Filozoficzna szkoła Iwowsko-warszawska, dz. cyt., 290. Joanna Rutkowska-Hajduk stwierdzi znacząco, że „świadomie unikanie przez Ossowską rozstrzygnięcia genezy norm moralnych oraz preferowany przez nią relatywizm kulturowy również jest zapożyczeniem z teorii funkcjonalizmu" (WWW.ptta.pl/pef/pdf/ossowska.pdf [pobrano: 7.11.2016]). Odnotować jeszcze warto konstatację Pawła Smoczyńskiego: „W pracach Marii Ossowskiej nie znajdujemy próby zbudowania zwartego systemu etycznego, na którego szczycie widniałby jakiś jednoznacznie określony ideał i towarzyszące mu, także jednoznaczne, dyrektywy wykonawcze. Zdaniem autorki w sprawach moralności niepodobna niczego przesądzać ostatecznie i według jakiegoś jednego tylko szablonu”. P.J Smoczyński, Maria Ossowska jako teoretyk nauki o moralności i moralista, w: M. Ossowska, Podstawy nauki o moralności, (część I), Warszawa 2004, 41. 
do czynienia z czymś spójnym"21, jak również - jakże wymowny podsumowujący fragment z zakończenia Podstaw nauki o moralności: „rozdziały IX i X wyjaśniły nam, dlaczego próby wyraźnego wyodrębnienia oceny i normy moralnej pośród innych ocen i norm nie dały pozytywnego wyniku. Rozdział IX ujawnił płynność konturów tego, co moralne, przez zestawienie reguły moralnej z regułą prawną, obyczajową, regułą dobrego wychowania (...). Rozdział X pokazywał wielotorowość $\mathrm{w}$ samej problematyce moralnej oraz rozmaite załamywanie się tej problematyki w różnych środowiskach społecznych"22. Wydaje się jednak, że Ossowska - mimo wnikliwości i neopozytywistycznej skrupulatności własnych badań ${ }^{23}$ - stawia błędną

21 M. Ossowska, Podstawy nauki o moralności, dz. cyt., 345.

22 Tamże, 394.

23 Mając świadomość, że szkoła lwowsko-warszawska powstała 30 lat przed powstaniem Koła Wiedeńskiego, jak również krytycznego stosunku Jana Woleńskiego do „mitu polskiego neopozytywizmu" (por. J. Woleński, dz. cyt., 305) za zasadne uznajemy użyte w tekście sformułowanie. Tadeusz Biesaga o szkole Iwowsko-warszawskiej - do której wszak należała Maria Ossowska - pisze, że „postrzegana jako nurt neopozytywizmu, podzielała z logicznym empiryzmem antymetafizyczną postawę, wiarę w nauki ścisłe i skuteczność analizy logicznej” (T. Biesaga, Ossowska Maria, dz. cyt., 890), a Jan Woleński (odnosząc się do szkoły lwowsko-warszawskiej i neopozytywizmu) zauważa: „Obie te szkoły miały wiele wspólnego, zwł. podzielały negatywny stosunek do metafizyki i wiarę w skuteczność analizy logicznej w rozważaniach filozoficznych (...). W ogólności, filozofowie ze sz. I.-w. podkreślali, iż metafilozoficzne stanowisko neopozytywizmu jest zbyt restryktywne i aprioryczne, po prostu »nieostrożne« - jak często mówiono. Te ogólne różnice nie przekreślają jednak podobieństw w kwestiach szczegółowych”. J. Woleński, Lwowsko-Warszawska Szkoła, http://www.ptta.pl/pef/pdf/l/Iws.pdf [pobrano: 17.11.2017]. Doniosłe jest także zarówno twierdzenie Stanisława Kowalczyka, że „była to swoista odmiana neopozytywizmu, którego charakterystycznym rysem był ekstremalny empiryzm podważający pośrednio autonomię filozofii w jej klasycznym rozumieniu" (S. Kowalczyk, Jak wykładać teodyceę dzisiejszym czytelnikom w Polsce?, http://cybra.lodz.pl/Content/8793/LST_2000_17do30.pdf [pobrano: 17.11.2017]), jak również uwaga Wojciecha Pawlika (powstała przy okazji omawiania książki Wojciecha Misztala, Homo ethicus homo moralis. Marii Ossowskiej koncepcja socjologii moralności, Wydawnictwo Naukowe Scholar, Warszawa 2017), że „Maria Ossowska rozpoczęła swoją podróż intelektualną jako badaczka związana z neopozytywistyczną szkołą lwowsko-warszawską". W. Pawlik, http://scholar.com.pl/sklep.php?md=products\&id_p=2664 [pobrano: 17.11.2017]. 
diagnozę wspomnianego niepowodzenia. Jego przyczyną bowiem nie jest wcale faktyczność moralna z jej ptynnościq konturów czy wielotorowośc w samej problematyce moralnej, które to elementy zdają się być oczywistą składową moralności rozumianej jako określony fakt społeczny wchłaniający zresztą jakąkolwiek utrwaloną formę kodyfikacji moralnej normatywności. Trudno przecież przypuszczać, aby faktyczna moralność - przy wyjściowym i postulowanym uwzględnieniu różnorodności opinii moralnych i systemów etycznych - mogła w spojrzeniu badacza moralności być pozbawiona zasadniczej polifoniczności ${ }^{24}$. Maria Ossowska miała zresztą tego świadomość już w punkcie wyjścia swych rozważań - w trakcie eksplikacji głównych postulatów swej koncepcji nauki o moralności. Skoro bowiem już wówczas twierdziła, że „trudno czasem w odniesieniu do pewnego określonego postępowania powiedzieć, czy mieliśmy do czynienia z nietaktem, czy też z czymś, co podlega ujemnej kwalifikacji moralnej; jak trudno w stosunku do pewnych reguł zdecydować, czy mamy do czynienia $z$ regułami dobrego wychowania, czy też $\mathrm{z}$ regułami, których przekroczenie dyskwalifikuje nie tylko towarzysko, ale i moralnie" 25 i skoro ta sama myśl stanowi jednocześnie

24 Wszakże „psychiczny fakt przeżywania moralności przez ludzi - pisze Tadeusz Styczeń znajduje swój wyraz zewnętrzny w ich działaniu, przede wszystkim w ich zachowaniu się w stosunku do drugich jako partnerów współżycia. Tego rodzaju zachowanie się jest już pewnym faktem społecznym. Zachowania te ulegają zresztą kolejnym zróżnicowaniom w zależności od tego, do jakich grup społecznych przynależą podmioty odnośnych przeżyć i zachowań moralnych”. T. Styczeń, Zarys etyki. Metaetyka, dz. cyt., 23. Tadeusz Ślipko konstatuje, że „konkretne akty ludzkie są niewątpliwie wszechstronnie zróżnicowane” (T. Ślipko, Zarys etyki szczegółowej, t. 1, Kraków 1982, 11), a Andrzej Szostek zauważa, że „celem etologii jest opis moralności, przez którą rozumie się tu zespół moralnych przekonań, przeżyć, a także podległych ocenie moralnej zachowań jednostek i grup społecznych, oraz wyjaśnienie moralności przez kulturowe, historyczne, psychologiczne i społeczne uwarunkowania. Nieostrość i złożona struktura przedmiotu etologii (czyli moralności) domaga się różnych metod jego badania (...), przez co badania etologiczne mają charakter interdyscyplinarny". A. Szostek, Etologia w aspekcie psychosocjologicznym, w: Powszechna encyklopedia filozofii, red. A. Maryniarczyk i in., t. 3, dz. cyt., 253.

25 M. Ossowska, Podstawy nauki o moralności, dz. cyt., 13. 
składową konkluzji badań ${ }^{26}$, to uprawnia to nas do twierdzenia, że Maria Ossowska nie tyle odkrywa niejasność statusu normy moralnej (i przyczynę tegoż) dopiero w finale swych rozważań, ile ją dostrzega od samego początku, jak też stara się to nieustannie wyeksponować.

Inaczej mówiąc - w perspektywie naszej badawczej hipotezy naukowa eksploracja moralnej normatywności, którą dokonuje Maria Ossowska, de facto stanowi jedynie sukcesywną prezentację kolejnego elementu uzasadniającego tezę, że ścisłe sprecyzowanie statusu normy moralnej jest niemożliwe. Oznacza to, że faktyczny dyskurs nauki o moralności nie tyle dochodzi do odkrycia niejasności i niejednoznaczności moralnej normatywności, ile od tych atrybutów wychodzi! Korelatywnie do tego - zgodnie ze znaczeniem przypisywanym normie moralnej jako metodycznemu środkowi mającemu pomóc w uchwyceniu samej moralności ${ }^{27}$ - już u zarania swoich etologicznych badań Ossowska zdaje się dysponować doświadczalnym wglądem w fakt wielokontekstowości i wieloaspektowości moralności rozumianej jako zróżnicowany i wielopostaciowy fakt społeczny i psychologicznya większość analiz stanowi jedynie opracowywanie tegoż wglądu; fakt, który można określić także jako zestaw różnorodnych opinii innych ludzi na temat tego, czym jest moralnosic 28 .

W tym momencie może pojawić się zarzut kierowany przeciwko powyższym supozycjom, wsparty na wielości pozytywnych wypowiedzi Ossowskiej, w których zdaje się jednak ona w swoisty sposób prezentować własny akces w sferę normatywno-moralną.

26 Por. przypis 22 niniejszej rozprawy.

27 „Wyłuskiwanie oceny i normy moralnej spośród innych ocen i norm - oto (...) zagadnienie, które w innych słowach jest zagadnieniem, czym jest i czym nie jest moralność". M. Ossowska, Podstawy nauki o moralności, dz. cyt., 12.

28 Paweł Smoczyński wskazuje na specyfikę „paradygmatu uprawiania nauki o moralności, któremu hołdowała Maria Ossowska. Zgodnie z tym paradygmatem zadaniem nauki o moralności jest w miarę możliwości dokładny i wyczerpujący opis zjawisk zaliczanych w jakiejś społeczności do rzędu zjawisk moralnych”. P.J Smoczyński, Maria Ossowska jako teoretyk nauki o moralności i moralista, dz. cyt., 35. 
„Przyłączam się do opinii Bertranda Russella - pisze Ossowska który w roku 1958 pisał: »Bez moralności obywatelskiej społeczeństwa giną; bez moralności osobistej nie są warte przetrwania" "29. Przy okazji refleksji wokół naruszania prywatności Ossowska zauważa, że „nie przywykliśmy włączać tego rodzaju norm do norm moralnych, ale nie widać żadnego powodu, by im tego miejsca odmawiać. Są one wszak wyrazem szacunku dla człowieka" ${ }^{30}$, a nieco dalej pada stwierdzenie, że „wytrwałość, z jaką ktoś dokucza sublokatorowi, by go zmusić do wyprowadzki, nie jest chwalebna (...). Odwaga budzi podziw nawet wtedy, gdy nie służy dobrej sprawie i z tego powodu włączenie jej do cnót osobistych wydaje mi się uzasadnione"31. Jeżeli mamy także świadomość, że Maria Ossowska buduje własny konkretny ideał obywatela obejmujący kilkanaście postulowanych wartości, wśród których występują także wartości moralne, ${ }^{32}$ to powstać może wątpliwość co do trafności naszych wcześniejszych ustaleń.

Skoro bowiem Ossowska faktycznie porusza się w przestrzeni normatywno-moralnej i skoro odnajdujemy w jej refleksji etycznej komponenty etyki normatywnej, to czy da się utrzymać eksponowaną uprzednio tezę o etologicznym zagubieniu oryginalności moralnej normatywności generującej jednocześnie niejasność i nieprecyzyjność zarówno samej normy, jak i moralności jako takiej? Inaczej mówiąc czy nie popełniliśmy błędu przypisując koncepcji nauki o moralności moc unicestwiania specyficznej, moralnej imperatywności normy moralnej, jak również uznając, że moralność w perspektywie Ossowskiej staje się kompleksem cudzych opinii o moralności?

Wykazując niesłuszność ostatnich wątpliwości, możemy stwierdzić, że wskazane wyżej cytaty nie tyle stanowią faktyczne naukowe (w rozumieniu samej Ossowskiej!) motywy etyczno-normatywne, ile

29 M. Ossowska, Normy moralne. Próba systematyzacji, Warszawa 1970, 75.

30 Tamże, 112.

31 Tamże, 226.

32 Por. taż, Wzór obywatela w ustroju demokratycznym, w: taż, O człowieku, moralności i nauce. Miscellanea, dz. cyt., 354-366. 
są zestawem wypowiedzi - posłużmy się określeniem Romana Ingardena - katechizmowych, czyli takich, które wprawdzie mają postać normatywną, jednak pozbawione są korelatu w postaci naukowego uzasadnienia ${ }^{33}$. Wypowiedzi te niewątpliwie odsłaniają pozytywnie osobistą moralną postawę Ossowskiej, jednak mieszczą się one $\mathrm{w}$ metaetycznym emotywizmie ${ }^{34}$.

Warto w tym miejscu przytoczyć fragment wywiadu z Ossowską, która na pytanie ,jakimi kryteriami i z jakiego piętra świadomości można wartościować poszczególne doktryny etyczne?"35, odpowiada, że „kwestia wartościowania nie jest z pewnością kwestią kryteriów intelektualnych, lecz e m o c jo n a $1 \mathrm{n}$ e g o a k c e s u (podk. W.K.)"36. Konstatacja ta zdaje się współbrzmieć zarówno z twierdzeniem, że wprawdzie „normy jakoś jednak uzasadnić można. Nie można tylko (...) dać pierwszeństwa żadnemu $\mathrm{z}$ dwóch sprzecznych ze sobą ich systemów" 37 , jak i z - uwikłaną w emocjonalny subiektywizm - propozycją poprzedzającą prezentację wzoru obywatela: „Zastanówmy się teraz, jakie rysy pragnęlibyśmy widzieć u kogoś, kto żyje w tak ukształtowanym społeczeństwie" 38 . W świetle tych wypowiedzi wydaje się zasadne nasze wcześniejsze przypuszczenie, że wtręt normatywno-moralny Ossowskiej pozostaje wyłącznie tym, czym może być w świetle postulatów jej koncepcji nauki o moralności - wyrazem pozanaukowej, obiektywnie nieuzasadnianej etycznej postawy

33 Por. R. Ingarden, Wykłady z etyki, dz. cyt., 29.

34 Emotywizm stanowi wariant metaetyki, według którego normy i oceny „moralne typu "x jest dobre« są pseudozdaniami: pozornie stwierdzają coś o przedmiocie, faktycznie jednak podmiot za ich pomocą wyraża swą irracjonalną, emocjonalną postawę (...) i skłania interlokutora do zajęcia postawy podobnej". A. Podsiad, Emotywizm, w: tenże, Słownik terminów i pojęć filozoficznych, dz. cyt., 224n. Por. S. Kamiński, T. Styczeń, Doświadczalny punkt wyjścia, Studia Philosophiae Christianae 4(1968)2, 27n.

35 Moralność: postęp czy regres (Rozmowa z prof. Mariq̨ Ossowską), w: O człowieku, moralności i nauce. Miscellanea, dz. cyt., 524.

36 Tamże, 524.

37 M. Ossowska, Podstawy nauki o moralności, dz. cyt., 158.

38 Taż, Wzór obywatela w ustroju demokratycznym, dz. cyt., 357. 
autorki; postawy, która wprawdzie ujawnia się we wspomnianych motywach etyczno-normatywnych, które jednak same w sobie są tylko pewną uczuciową emanacją i uprawniają do przypisania Ossowskiej emotywizmu ${ }^{39}$.

Spróbujmy obecnie przyjrzeć się bliżej drugiemu komponentowi tytułowego dwugtosu w szkole lwowsko-warszawskiej, czyli normatywności moralnej osadzonej w perspektywie etyki empirycznej Tadeusza Czeżowskiego.

\section{KU NAUKOWOŚCI NORMATYWNOŚCI MORALNEJ}

Radykalnie odmiennym wariantem refleksji etycznej, dokonującym się w ramach szkoły lwowsko-warszawskiej, jest koncepcja etyki empirycznej proponowana przez Tadeusza Czeżowskiego, która odsłania swą istotę w trakcie wglądu filozofa w istniejące systemy etyczne. Spoglądając z tej perspektywy metaetycznej, Czeżowski zwraca uwagę na empiryczne osadzenie systemów etycznych. „Mówię o etyce jako nauce empirycznej - twierdzi logik - gdyż sądzę, że ma za przedmiot fakty etyczne stwierdzane w ocenach etycznych (...). Rozróżniam oceny pierwotne i wtórne (...). Owe oceny pierwotne uważam za intuicyjne tak jak sądy spostrzeżeniowe" ${ }^{40}$. W innym miejscu Czeżowski stwierdza: „uważam etykę za naukę empiryczną, zdaniami empirycznymi są bowiem oceny pierwotne jako jej przesłanki (...)”41, a także, że „prawdziwa jest ocena stwierdzająca wartość przedmiotu zawsze tylko, jeżeli przedmiot jest wartościowy"42.

Powyższe określenia wyznaczają samo sedno spojrzenia Czeżowskiego na etykę. Ta ostatnia bowiem w swej istocie ma wymiar

39 Por. A. Podsiad, Emotywizm, dz. cyt., 224n; S. Kamiński, T. Styczeń, Doświadczalny punkt wyjścia, dz. cyt., 27n., przypis 5.

40 T. Czeżowski, Uwagi o etyce jako nauce empirycznej, w: Pisma z etyki i teorii wartości, red. P.J. Smoczyński, Wrocław-Warszawa-Kraków-Gdańsk-Łódź 1989, 105, 107.

41 Tenże, Konflikty w etyce, w: tenże, Pisma z etyki i teorii wartości, dz. cyt., 143.

42 Tenże, Etyka jako nauka empiryczna, w: tenże, Pisma z etyki i teorii wartości, dz. cyt., 98. 
z gruntu anty-etologiczny w tym sensie, że system etyczny genetycznie zakorzeniony jest $\mathrm{w}$ faktycznie istniejącej (i danej doświadczalnie) rzeczywistości. Do owej rzeczywistości moralnej, czyli do wspomnianych przez Czeżowskiego faktów moralnych, poznający je podmiot dociera właśnie poprzez oceny pierwotne. One stanowią poznawczy fundament dla konstrukcji całego systemu etycznego, czyli - jak to ujmie Ryszard Wiśniewski - „wyjściowy materiał empiryczny"43. Jego oryginalność polega, z jednej strony, na tym, że dotyczy on wartości jako szczególnego aspektu bytowości, natomiast $z$ drugiej strony - może on być przedmiotem naukowej procedury sprawdzającej zasadność wyjściowych ocen pierwotnych. Koncepcja oceny pierwotnej pozwala na związanie (przyporządkowanie) ze sobą wartości moralnej - która w perspektywie Czeżowskiego przestaje być jedynie subiektywnym pogłosem uczuciowości ${ }^{44}$ - i naukowych standardów.

Tym samym Czeżowski stwarza sobie możliwość nałożenia na dyskurs etyczny naukowej matrycy - tak znaczącej w kontekście priorytetów szkoły lwowsko-warszawskiej - która nie tylko uwalnia od relatywizującego emotywizmu, lecz przywraca etyce miejsce na kategorię naukowej prawdy. Wszakże „zakładam, że przesłankami wszelkich sądów oceniających są jednostkowe o postaci »to jest wartościowe (piękne, dobre, itp.)«, uważam je za obiektywne w równej mierze, jak wszelkie stwierdzenia empiryczne" 45 . Jednostkowe oceny

43 R. Wiśniewski, Doświadczenie aksjologiczne a teorie etyczne w koncepcji Tadeusza Czeżowskiego, w: tenże, Człowiek i wartości moralne. Studia z dziejów polskiej niezależnej myśli etycznej, red. Z.J. Czarnecki, S. Soldenhoff, Lublin 1989, 267.

44 Czeżowski stwierdza zarówno, że „nie jest przeto ocena uwarunkowana przez uczucie jako motyw jej wydania, lecz przeciwnie - oba rodzaje uczuć związanych z ocenami, tj. uczucia estetyczne i uczucia wartości, opierają się na ocenie - przyjemność lub przykrość pojawia się na tle wydania oceny” (T. Czeżowski, Etyka jako nauka empiryczna, dz. cyt., 99), jak i twierdzi, że „elementem pierwotnym jest sąd oceniający, elementem wtórnym przyjemność lub przykrość". Tenże, Etyka a psychologia i logika, w: tenże, Pisma z etyki i teorii wartości, dz. cyt., 110.

45 Tenże, Jak budować logikę dóbr? (1), w: tenże, Pisma z etyki i teorii wartości, dz. cyt., 130. 
pierwotne zatem dostarczają wiedzy o wartościach („przypisaliśmy ocenom cechę prawdziwości, tworzą one wiedzę"46), a nie wiedzy o indywidualnych przekonaniach osób oceniających. Skoro - pisze Czeżowski - „zakładamy jako prawdziwe nie to, że $p$ jest treścią czyjegoś przekonania, lecz wprost $p$ "47, to system etyczny analitycznie eksplorowany przez omawianego logika wspiera się na fundamencie naukowym i pretenduje do prawdziwości ${ }^{48}$.

Ostatnie uwagi mają doniosłe znaczenie dla problematyki moralnej normatywności, która genetycznie wywodzi się (przynajmniej w kontekście norm aksjologicznych ${ }^{49}$ ) właśnie $\mathrm{z}$ wielości ponawianych ocen pierwotnych, które - jako ponawiane i dotyczące wartości tego samego przedmiotu - mogą być uogólniane dzięki czemu zyskuje się kryterium oceniania. „Przedmioty lub zdarzenia indywidualne pisze Czeżowski - oceniane w ocenach pierwotnych jako dobre, mają pewne cechy wyróżniające je spośród innych przedmiotów lub zdarzeń: one są dobre, będąc takie a takie. Owo takie a takie staje się kryterium dobra przez uogólnianie mające charakter założenia: "takie a takie rzeczy są dobre " 50 . Przykładowymi kryteriami dobra (wartości ${ }^{51}$ ) są takie empiryczne (!) znamiona danej ludzkiej aktywności, jak ofiarność, roztropność, miłosierdzie ${ }^{52}$. Wspomniane kryteria

46 Tenże, Etyka jako nauka empiryczna, dz. cyt., 103.

47 Tamże, 103.

48 Por. tenże, O metodzie opisu analitycznego, w: tenże, Pisma z etyki i teorii wartości, dz. cyt., 68nn; Uwagi o etyce jako nauce empirycznej, dz. cyt., 108; D. Łukaszewicz, Filozofia Tadeusza Czeżowskiego, Bydgoszcz 2002, 114nn., 276.

49 O zróżnicowaniu norm aksjologicznych (teleologicznych) i deontycznych powiemy w dalszej części artykułu.

50 T. Czeżowski, Etyka jako nauka empiryczna, dz. cyt., 107.

51 Czeżowski traktuje zamiennie termin wartość i dobro. Pisze m.in., że „postawa moralna pozwala poznać jego dobro (wartość moralną) (...)". Tenże, Klasyfikacja rozumowań i jej konsekwencje w teorii nauki, w: tenże, Pisma z etyki i teorii wartości, dz. cyt., 83; por. Aksjologiczne i deontyczne normy moralne, w: tenże, Pisma z etyki i teorii wartości, dz. cyt., 153.

52 Por. tenże, Etyka jako nauka empiryczna, dz. cyt., 99; Aksjologiczne i deontyczne normy moralne, dz. cyt., 153. 
stanowią kolejne piętro (wobec ocen pierwotnych) w systemie etycznym, które pozwala zarówno na ukonstytuowanie ogólnego prawa etycznego (zasady etycznej) ${ }^{53}$, jak i na formułowanie ocen wtórnych. Prawo etyczne (zasada etyczna) staje się uogólnioną formułą obejmującą kryterium oceny stanowiące jednocześnie wspomniane kryterium dobra. Jeżeli bowiem dysponujemy już wiedzą o tym, że takim samym czynom w wielości ocen pierwotnych przypisaliśmy wartość (dobro) a jednocześnie owe czyny posiadają takie same empiryczne atrybuty (pewną takość) - miłosierdzie czy ofiarność - to tę wiedzę sformalizować można na poziomie ogólnego prawa etycznego: „takie a takie rzeczy są dobre lub złe"54, które skonkretyzowane może mieć postać: postępowanie mitosierne jest dobre. Takie prawo pełni jednocześnie funkcję prawa kryjącego kryterium oceny wtórnej - wszak wiedząc, że miłosierdzie jest kryterium dobra (wartości), mogę w oparciu o tę wiedzę oceniać inne czyny jako dobre (wartościowe), skoro posiadają w sobie kryterialną takość, np. miłosierdzie czy ofiarność 55 .

W tym momencie docieramy do najbardziej dla nas doniosłego poziomu systemu etycznego rozważanego przez Czeżowskiego, czyli do poziomu normatywno-moralnego, który zdaje się być czytelną konsekwencją dotychczasowych ustaleń. Jeżeli bowiem istnieje wiedza aksjologiczno-moralna dotycząca zarówno wartościowych (dobrych) działań i jednocześnie owe działania specyfikowane są przez

53 Czeżowski stosował oba te terminy na oznaczenie tej samej ogólnej formuły będącej uogólnieniem ocen elementarnych. Por. tenże, Etyka jako nauka empiryczna, dz. cyt., s. 100; Uwagi o etyce jako nauce empirycznej, dz. cyt., 107; Etyka jako nauka empiryczna, w: tenże, Odczyty filozoficzne, Toruń 1958, 63, 64; D. Łukaszewicz, Filozofia Tadeusza Czeżowskiego, dz. cyt., 274.

54 T. Czeżowski, Etyka jako nauka empiryczna, w: tenże, Pisma z etyki i teorii wartości, dz. cyt., 100.

55 Por. tenże, O etyce niezależnej Tadeusza Kotarbińskiego, w: tenże, Pisma z etyki i teorii wartości, dz. cyt., 163; Etyka a psychologia i logika, dz. cyt., 110. „Oceny wtórne - pisze Czeżowski - są rezultatem zastosowania do ocenianego przypadku jakiegoś poprzednio ustalonego kryterium (...), oceniany przypadek zostaje podporządkowany pod jakieś prawo etyczne". Tenże, Etyka jako nauka empiryczna, dz. cyt., 101. 
pewne kryterialne (empiryczne) znamiona, to postulat podejmowania działań zawierających owe znamiona jest oczywisty. Skoro więc „przedmioty lub zdarzenia spełniające kryteria dobra nazywamy dobrami (...), [to - W. K.] „istnieje równoważność między oceną "takie a takie rzeczy są dobrami« a normą »takie a takie rzeczy należy realizować" «56. W innym miejscu Czeżowski stwierdza, że „ocena »to a to jest moralnie dobre « tworzy normę »to a to właśnie należy obrać jako cel postępowania " 57 , czego egzemplifikacją jest formuła „pomagać w biedzie jest rzeczą dobrą, więc tak należy czynić” 58 .

W perspektywie dotychczasowych analiz uzasadnione jest więc twierdzenie, że rozważana dotychczas aksjologiczna (teleologiczna) normatywność moralna ${ }^{59}$ wyrasta $\mathrm{z}$ pretendujących do prawdziwości ocen pierwotnych i jako taka również aspiruje do naukowej prawdziwości. Wspomniane normy aksjologiczne pod względem strukturalnym są zdaniami powinnościowymi, o których Czeżowski powie, że „zdania powinnościowe: "powinno się postąpić tak a tak" (...), stwierdzają powinność $[\mathrm{i}-\mathrm{W}$. K] są prawdziwe lub fałszywe, co okazuje się, jeżeli poprzedzimy je zwrotem "jest prawdą, że..." lub »nie jest prawdą, że...»"60. Normy aksjologiczne zatem prawdziwie bądź fałszywie informują o powinności moralnej a jednocześnie spełniają standardy naukowe dotyczące ich uzasadniania, czyli „wskazywania podstawy uznania za prawdziwe zdań, w których formułujemy żywione przez nas sądy" ${ }^{1}$. Ostatecznym bowiem poziomem uzasadniającym moralną normatywność aksjologiczną są oceny pierwotne - ujmujące wartość - które są równie wiarygodne

56 Tenże, Etyka a psychologia i logika, dz. cyt., 110.

57 Tenże, Aksjologiczne i deontyczne normy moralne, dz. cyt., 150.

58 Tamże, 154.

59 Czeżowski posługiwał się obu terminami na oznaczenie norm moralnych, które genetycznie osadzone są w ocenach pierwotnych stwierdzających obecność wartości a wprost dokonał ich utożsamienia w Aksjologicznych i deontycznych normach moralnych. Por. tamże, 150n.

60 T. Czeżowski, Dwojakie normy, w: tenże, Pisma z etyki i teorii wartości, dz. cyt., 144.

61 Z. Ziembiński, Logika praktyczna, Warszawa 1997, 144. 
pod względem naukowym, jak każde inne sądy spostrzeżeniowe empiryczne stanowiące fundament teorii naukowych ${ }^{62}$. Jak pisze sam Czeżowski: „oceny elementarne oraz ich uogólnienia są przeto uzasadnione empirycznie (...). Tak samo są też uzasadnione normy aksjologiczne określone przez oceny"63.

Normatywność moralna w ujęciu Czeżowskiego jednak posiada jeszcze jeden wymiar, poniekąd komplementarny wobec normy aksjologicznej (teleologicznej), a równocześnie tworzący jeszcze wyższe piętro w systemie etycznym eksplorowanym w paradygmacie etyki empirycznej. Chodzi tutaj o normatywność o charakterze apriorycznym pełniącą funkcję etycznych aksjomatów ${ }^{64}$, której istotny sens związany jest z tym, że normatywność aksjologiczna (wsparta o empirię aksjologiczną) może rodzić sytuacje konfliktowe pomiędzy dwiema powinnościami, np. powinnością prawdomówności i powinnością unikania cierpienia drugiego człowieka. „Potrzebna jest wówczas - pisze Czeżowski - (...) inna norma (...), która by regulowała stosowanie norm teleologicznych"65. Przykładem takiej nadrzędnej normy deontycznej (zwanej czasami zasadą ${ }^{66}$ ) jest imperatyw kategoryczny Kanta, zasada życzliwości powszechnej czy zasada miłości

62 Czeżowski stwierdza, że „przesłankami dla norm teleologicznych są (...) oceny jednostkowe, analogiczne do zdań obserwacyjnych w naukach przyrodniczych" (T. Czeżowski, Etyka a psychologia i logika, dz. cyt., 112.) a także, że „przesłankami wszelkich sądów oceniających są oceny jednostkowe o postaci »to jest wartościowe (piękne, dobre itp.) «, uważam je za obiektywne w równej mierze, jak wszelkie stwierdzenia empiryczne". Tenże, Jak budować logikę dóbr? (1), dz. cyt., 130. Por. tenże, Dwojakie normy, dz. cyt., 147.

63 Tenże, Aksjologiczne i deontyczne normy moralne, dz. cyt., 153.

64 Por. tenże, Etyka a psychologia i logika, dz. cyt., 112; Konflikty w etyce, w: Pisma z etyki i teorii wartości, dz. cyt., 142.

65 Tenże, Konflikty w etyce, dz. cyt., 141. Por. tamże, 142.

66 Tej zasady nie wolno oczywiście mylić z terminem zasada odnoszonym przez pewien czas przez Czeżowskiego do praw etycznych ustalających - w formie uogólnień ocen pierwotnych - kryteria wartości (dobra). Por. przypis 53 niniejszej rozprawy; T. Czeżowski, Aksjologiczne i deontyczne normy moralne, dz. cyt., 151, przypis 1; Konflikty w etyce, dz. cyt., $141 \mathrm{nn}$. 
bliźniego ${ }^{67}$. Każda z wymienionych norm deontycznych w szczególny sposób unifikuje dany system etyczny i wyznacza niejako szerszą perspektywę umożliwiającą rozeznanie konkretnych sytuacji moralnych. Pomimo ewentualnej prawdziwości norm aksjologicznych - które nie tracą swej zasadności wspartej na wielości ocen elementarnych - to właśnie wiedza o nadrzędnej normatywności umożliwia ich szczególne wzajemne uzgodnienie poprzez dostosowywanie ich do aksjomatycznej dyrektywy deontycznej. Taka norma „przyjmuje pojęcie obowiązku jako pierwotne, stąd wynika, że postępując według obowiązku zgodnie z normą, realizujemy dobro moralne"68.

Oba typy normatywności występują - wprawdzie w różnej proporcji - we wszystkich systemach etycznych, jednak Czeżowski wyróżnia etyki aksjologiczne (wspierające się na ocenach pierwotnych) oraz etyki deontyczne (budowane odgórnie jako hipotetyczno-dedukcyjne systemy aksjomatyczne ${ }^{69}$.

Dla nas istotne jest jednak to, że każda $\mathrm{z}$ omówionych normatywności moralnych (i korelatywnie: typów etyk) jest zanurzona w empirię aksjologiczną, a tym samym spełnia standardy naukowości; każda $z$ nich bowiem podlega ciągłemu procesowi naukowego sprawdzania, które ewentualnie powiększa probabilistycznie ich prawdziwość. W przypadku normatywności aksjologicznej każda kolejna ocena pierwotna zbieżna $\mathrm{z}$ ocenami elementarnymi, które stanowiły fundament dla ich uogólnień prowadzących do owej normy aksjologicznej, potwierdza (probabilistycznie!) jej prawdziwość bądź też zdaje się postulować pewną modyfikację owej normatywności. „Empiria moralna - pisze Czeżowski - podobnie jak empiria przyrodnicza, nigdy nie daje wyników ostatecznych, tzn. każda norma moralna, jako uogólnienie jednostkowych doświadczeń moralnych,

67 Por. tenże, Aksjologiczne i deontyczne normy moralne, dz. cyt., 150.

68 Tamże, 150.

69 Por. tenże, O etyce niezależnej Tadeusza Kotarbińskiego, dz. cyt., 164n. 
w nowej sytuacji może się okazać niewystarczająca i wówczas będzie wymagać odpowiedniego zaadoptowania" 70 .

Również normatywność deontyczna (i systemy deontyczne) posiada dwukierunkowe osadzenie empiryczne. $Z$ jednej strony - skoro konstruowana jest aksjomatycznie metodą analityczną - źródłowo pretenduje do wyidealizowanego i modelowego ujęcia pewnej empirycznej rzeczywistości ${ }^{71}$, $\mathrm{z}$ drugiej zaś strony poziom jej obowiązywania jest weryfikowany właśnie drogą empiryczną. Wszakże „pole empirii aksjologicznej - pisze Ryszard Wiśniewski - jest obszarem semantycznej interpretacji etyki aksjomatycznej, sprawdzianem jej stosowalności, dowodem zdolności regulowania postaw, rozwiązywania konfliktów"72.

\section{PODSUMOWANIE}

Normatywność moralna w optyce Czeżowskiego - przynajmniej postulatywnie - jest wolna od etologicznej anihilacji. W obu komponentach (aksjologicznym i deontycznym) spełnia standardy naukowych teorii, budowanych indukcyjnie i aksjomatycznie, i stanowi zestaw uzasadnianych empirycznie zdań logicznych podpadających

70 Tenże, Konflikty w etyce, dz. cyt., 140. System etyczny - analogicznie jak inne kompleksy zdań tworzących teorię naukową - jest sprawdzany poprzez jednostkowe doświadczania (tu: oceny pierwotne). Por. tenże, W sprawie zagadnienia indukcji, w: tenże, Odczyty filozoficzne, dz. cyt., 122n; Etyka jako nauka empiryczna, dz. cyt., 101nn; O etyce niezależnej Tadeusza Kotarbińskiego, dz. cyt., 163, 165.

71 Istotne jest by „egzemplarz wybrany jako przedmiot opisu był typowy, tzn. reprezentował istotne własności desygnatów nazwy". T. Czeżowski, O metodzie opisu analitycznego, dz. cyt., 71. „Etyka deontyczna - pisze Czeżowski - (...) daje abstrakcyjny model społeczności, w której obowiązuje". Tenże, Aksjologiczne i deontyczne normy moralne, dz. cyt., 154. Por. tenże, O etyce niezależnej Tadeusza Kotarbińskiego, dz. cyt., 166n.; R. Wiśniewski, Problem z kryteriami wartości. w nawiązaniu do aksjologii Tadeusza Czeżowskiego, w: Tadeusz Czeżowski (1889-1981). Dziedzictwo idei: logika - filozofia - etyka, red. W. Tyburski, R. Wiśniewski, Toruń 2002, 156.

72 R. Wiśniewski, Problem z kryteriami wartości. W nawiązaniu do aksjologii Tadeusza Czeżowskiego, dz. cyt., 156. 
pod kategorię prawdy. W konsekwencji koncepcja normatywności moralnej autorstwa Czeżowskiego stanowi doniosły kontrapunkt wobec ujęcia Marii Ossowskiej. Do obu modeli refleksji etycznej niewątpliwie ma zastosowanie charakterystyka programu etycznego szkoły lwowsko-warszawskiej Jana Woleńskiego, który twierdzi, iż „uważano po prostu, że w etyce możliwa jest i racjonalna dyskusja, i racjonalna argumentacja, a w aksjologii obowiązuje taki sam standard precyzji, jak w pozostałych działach filozofii"73. Jednak o ile egzemplifikacja owego programu w przypadku Marii Ossowskiej finalizuje w wchłonięciu normatywności moralnej poprzez dyskurs etologiczny (wraz z emotywistycznym osobistym komponentem), o tyle refleksja Tadeusza Czeżowskiego przywraca normom moralnym status zasadnych składowych empirycznych systemów etycznych.

W kontekście dotychczasowych badań można jednak pokusić się o pewną ogólniejszą refleksję metaetyczną. Uprawianie etyki w paradygmacie empirycznym może podnosić jakość metodologiczną dyskursu i poszerzać etologicznie wiedzę o faktycznych kontekstach socjologicznych czy psychologicznych fenomenu moralności (Maria Ossowska), jak również może rehabilitować status naukowy zdań etycznych i może wykazać paradygmatyczną doniosłość moralnej normatywności (Tadeusz Czeżowski). Pomimo tego jednak nawet ostatni wariant referowanego dwugtosu nie wyczerpuje istoty problematyki etycznej a poniekąd nawet go postuluje i to niejako dwukierunkowo.

Pierwszym kierunkiem okazuje się pogłębienie elementarności moralnego doświadczenia i sięgnięcie poza (a może przed) ocenę elementarną, ujmującą obecną już wartość. Zdaniem autora niniejszych analiz bowiem dyskurs etyczny winien wychodzić od źródłowości datum morale, której nieusuwalnym komponentem jest imperatywność dobiegająca $\mathrm{z}$ konkretnej konsytuacji moralnej wzywającej obligatoryjnie do konkretnego działania. To owa źródłowość zawiera

73 J. Woleński, Filozoficzna szkoła lwowsko-warszawska, dz. cyt., 284. 
w sobie obligatoryjne wotanie (normatywność w sensie najbardziej fundamentalnym), którą Ossowska radykalnie unicestwia a której Czeżowski nie dostrzega, umieszczając powinność normatywno-moralną dopiero na wyższym piętrze analizowanego przez siebie systemu etycznego. Tymczasem imperatywność powinności moralnej jest dana doświadczalnie przed(!) oceniającym stwierdzeniem, że to jest wartośc, które dopiero poprzez uogólnienie odkrywa miejsce dla normy aksjologicznej; jest dana jako element datum morale, która została w innym miejscu określona jako moralne wydarzanie się ${ }^{74}$.

Drugi kierunek refleksji sygnalizuje Czeżowski uznający wartość za modi entis ${ }^{75}$. To ontologiczne wyjaśnienie statusu wartości - stanowiące swoisty naddatek wobec dyskursu etycznego, którego zasadność w pełni (przy przyjętych principiach metodologicznych) wyczerpuje się w drodze doświadczenia aksjologicznego - jest symptomem etycznych aspiracji wyjaśniających, których nie da się utożsamić $\mathrm{z}$ aspiracjami uzasadniającymi. Te ostatnie mogą być zaspokojone poprzez precyzyjny i logicznie poprawny dyskurs (omówiony dwugtos jest egzemplifikacją tegoż) a mimo to wyjaśniająca i ontologiczna kontynuacja zdaje się odpowiadać dążeniom do budowania etyki fundamentalnej; etyki, która znajdzie miejsce zarówno dla integralnego doświadczenia faktu moralnego (moralnego wydarzania się), jak i komponentu uzasadniającego i składowej ontologicznego wyjaśniania sięgającej w głąb tajemnicy, którą Tadeusz Styczeń opisze formułą: „pytanie - udręka (...): »Dlaczego w ogóle cokolwiek winienem niż nic?»"76.

74 Por. W. Kmiecikowski, Etyka między doświadczeniem a ontologią. Krąpiec - Ingarden Czeżowski, Poznań 2013, 477-501.

75 Por. T. Czeżowski, Czym są wartości (wprowadzenie do dyskusji), w: tenże, Pisma z etyki i teorii wartości, dz. cyt., 118n; tenże, O naukach humanistycznych, tamże, 51n.

76 T. Styczeń, Problem możliwości etyki jako empirycznie uprawomocnionej i ogólnie ważnej teorii moralności. Studium metaetyczne, Lublin 1972, 36. Na temat owej etyki fundamentalnej - por. W. Kmiecikowski, Etyka między doświadczeniem a ontologią, dz. cyt., 447-475. 


\section{BIBLIOGRAFIA}

Biesaga T., Ossowska Maria, w: Powszechna encyklopedia filozofi, red. A. Maryniarczyk, t. 7, Polskie Towarzystwo Tomasza z Akwinu, Lublin 2006, 889-892.

Czeżowski T., Aksjologiczne i deontyczne normy moralne, w: Pisma z etyki i teorii wartości, red. P.J. Smoczyński, Wydawnictwo PAN, Wrocław-Warszawa-Kraków-Gdańsk-Łódź 1989, 150-156.

Czeżowski T., Czym sq wartości (wprowadzenie do dyskusji), w: Pisma zetyki i teorii wartości, red. P.J. Smoczyński, Wydawnictwo PAN, Wrocław-Warszawa-Kraków-Gdańsk-Łódź 1989, 117-119.

Czeżowski T., Dwojakie normy, w: Pisma z etyki i teorii wartości, red. P.J. Smoczyński, Wydawnictwo PAN, Wrocław-Warszawa-Kraków-Gdańsk-Łódź 1989, 144-149.

Czeżowski T., Etyka jako nauka empiryczna, w: Pisma z etyki i teorii wartości, red. P.J. Smoczyński, Wydawnictwo PAN, Wrocław-Warszawa-Kraków-Gdańsk-Łódź 1989, 97-104.

Czeżowski T., Etyka jako nauka empiryczna, w: Odczyty filozoficzne, PWN, Toruń 1958, 59-67.

Czeżowski T., Etyka apsychologiailogika, w: Pismazetyki iteorii wartości, red. P.J. Smoczyński, Wydawnictwo PAN, Wrocław-Warszawa-Kraków-Gdańsk-Łódź 1989, 109-112.

Czeżowski T., Jak budować logikę dóbr? (1), w: Pisma z etyki i teorii wartości, red. P.J. Smoczyński, Wydawnictwo PAN, Wrocław-Warszawa-Kraków-Gdańsk-Łódź 1989, 130-135.

Czeżowski T., Klasyfikacja rozumowań i jej konsekwencje w teorii nauki, w: Pisma z etyki i teorii wartości, red. P.J. Smoczyński, Wydawnictwo PAN, Wrocław-Warszawa-Kraków-Gdańsk-Łódź 1989, 77-89.

Czeżowski T., Konflikty w etyce, w: Pisma z etyki i teorii wartości, red. P.J. Smoczyński, Wydawnictwo PAN, Wrocław-Warszawa-Kraków-Gdańsk-Łódź 1989, 139-143.

Czeżowski T., O etyce niezależnej Tadeusza Kotarbińskiego, w: Pisma zetyki i teorii wartości, red. P.J. Smoczyński, Wydawnictwo PAN, Wrocław-Warszawa-Kraków-Gdańsk-Łódź 1989, 162-167.

Czeżowski T., O metodzie opisu analitycznego, w: Pisma z etyki i teorii wartości, red. P.J. Smoczyński, Wydawnictwo PAN, Wrocław-Warszawa-Kraków-Gdańsk-Łódź 1989, 68-76. 
Czeżowski T., O naukach humanistycznych, w:Pisma zetyki i teorii wartości, red. P.J. Smoczyński, Wydawnictwo PAN, Wrocław-Warszawa-Kraków-Gdańsk-Łódź 1989, 47-58.

Czeżowski T., Uwagio etyce jako nauce empirycznej, w: Pisma z etyki i teorii wartości, red. P.J. Smoczyński, Wydawnictwo PAN, Wrocław-Warszawa-Kraków-Gdańsk-Łódź 1989, 105-108.

Czeżowski T., Wsprawie zagadnienia indukcji, w: Odczyty filozoficzne, Towarzystwo Naukowe w Toruniu, Toruń 1958, 116-124.

Ingarden R., Wyktady z etyki, PWN, Warszawa 1989.

Kamiński S., Styczeń T., Doświadczalny punkt wyjścia, Studia Philosophiae Christianae 4(1968)2, 21-73.

Kmiecikowski W., Etyka między doświadczeniem a ontologiq. Krąiec-IngardenCzeżowski, Flos Carmeli, Poznań 2013.

Kowalczyk S., Jak wyktadać teodycee dzisiejszym czytelnikom w Polsce?, http://cybra. lodz.pl/Content/8793/LST_2000_17do30.pdf [pobrano: 7.11.2017].

Lazari-Pawłowska I., Maria Ossowska jako badacz moralności, w: taż, Etyka. Pisma wybrane, red. P.J. Smoczyński, Zakład Narodowy im. Ossolińskich, Wrocław-Warszawa-Kraków 1992, 431-448.

Łukaszewicz D., Filozofia Tadeusza Czeżorwskiego, Wydawnictwo Akademii Bydgoskiej, Bydgoszcz 2002.

Moralność: postęp czy regres (Rozmowa z prof. Mariq Ossowska), w: O cztowieku, moralności i nauce. Miscellanea, PWN, Warszawa 1983, 523-527.

Ossowska M., Jakie zadania ma przed sobq badacz moralności?, w: O cztowieku, moralności i nauce. Miscellanea, PWN, Warszawa 1983, 333-340.

Ossowska M., Normy moralne. Próba systematyzacji, PWN, Warszawa 1970.

Ossowska M., Podstawy nauki o moralności, PWN, Warszawa 1963.

Ossowska M., Wzór obywatela w ustroju demokratycznym, w: O człowieku, moralności i nauce. Miscellanea, PWN, Warszawa 1983, 355-366.

Pawlik W., http://scholar.com.pl/sklep.php?md=products\&id_p=2664 [pobrano: 7.11.2017].

Podsiad A., Etologia, w: tenże, Stownik terminów i pojęć filozoficznych, Instytut Wydawniczy PAX, Warszawa 2000, 240-241.

Podsiad A., Emotywizm, w: tenże, Stownik terminów i poję́filozoficznych, Instytut Wydawniczy PAX, Warszawa 2000, 224-225.

Rutkowska-Hajduk J, Ossowska Maria, WWW.ptta.pl/pef/pdf/o/ossowska.pdf [pobrano: 7.11. 2016]. 
Smoczyński P.J., Maria Ossowska jako teoretyk nauki o moralności i moralista, w: M. Ossowska, Podstawy nauki o moralności, (część I), De Agostini Polska, Warszawa 2004, 5-49.

Styczeń T., Etyka, w: Powszechna encyklopedia filozofii, red. A. Maryniarczyk i in., t. 3, Polskie Towarzystwo Tomasza z Akwinu, Lublin 2002, 269-284.

Styczeń T., Problem możliwości etyki jako empirycznie uprawomocnionej i ogólnie ważnej teorii moralności. Studium metaetyczne, KUL, Lublin 1972.

Styczeń T., Zarys etyki. Metaetyka, KUL, Lublin 1974.

Ślipko T., Zarys etyki szczegótowej, t. 1, Wydawnictwo Apostolstwa Modlitwy, Kraków 1982.

Szostek A., Etologia, w: Leksykon filozofii klasycznej, red. J. Herbut, Towarzystwo Naukowe KUL, Lublin 1997, 172-174.

Szostek A., Etologia w aspekcie psychosocjologicznym, w: Powszechna encyklopedia filozofii, red. A. Maryniarczyk i in., t. 3, Polskie Towarzystwo Tomasza z Akwinu, Lublin 2002, 253-254.

Wiśniewski R., Problem z kryteriami wartości. w nawiqzaniu do aksjologii Tadeusza Czeżowskiego, w: Tadeusz Tadeusz Czeżowski (1889-1981). Dziedzictwo idei: logika - flozofia - etyka, red. W. Tyburski, R. Wiśniewski, Wydawnictwo UMK, Toruń 2002, 145-159.

Wiśniewski R., Dośrwiadczenie aksjologiczne a teorie etyczne w koncepcji Tadeusza Czeżorwskiego, w: Cztowiek i wartości moralne. Studia zdziejów polskiej niezależnej myśli etycznej, red. Z.J. Czarnecki, S. Soldenhoff, Wydawnictwo Lubelskie, Lublin 1989, 259-287.

Woleński J., Filozoficzna szkota lwowsko-warszawska, PWN, Warszawa 1985.

Woleński J., Filozoficzna szkota lwowsko-warszarwska, http://www.ptta.pl/pef/ pdf/1/lws.pdf, [pobrano 07.11.2017].

Ziembiński Z, Logika praktyczna, PWN, Warszawa 1997.

\section{TWO DIFFERENT VIEWPOINTS IN THE LVOV-WARSAW SCHOOL. NORMATIVITY BETWEEN ETHOLOGY AND EMPIRICAL ETHICS}

Abstract. This article critically discusses the ethological and ethical-empirical perspec-
tives concerning the reflection on morality within the Lvov-Warsaw School. Focusing on
Maria Ossowska's research we highlight the tendency of ethological analysis to annihilate
the specificity of moral normativity (moral imperativeness), as well as the ambiguity of
Ossowska's conclusions and her predilection for emotivism. Similarly, an examination of
Tadeusz Czezowski's views reveals a propension to argue for the scientific (empirical) status
of axiological and deontic standards, which can be regarded as true or false statements. 
In conclusion, Maria Ossowska's and Tadeusz Czezowski's model of normativity is compared with the moral imperativeness available at the level of experimental moral philosophy.

Keywords: ethology, empirical ethics, science, normativity, moral imperativeness

\section{WALDEMAR KMIECIKOWSKI}

waldekkm@poczta.onet.pl

Wyższa Szkoła Humanistyczna im. Króla Stanisława Leszczyńskiego w Lesznie

Królowej Jadwigi 10, 64-100 Leszno

DOI: 10.21697/spch.2018.54.2.12 